\title{
CHURCH AND SOCIETY. THE ROLE OF RELIGIOUS JOURNALS IN THE DIFUSION OF THE BIBLICAL ELEMENT WITHIN THE HISTORICAL BANAT AREA. 1867-1918
}

\author{
Alin Cristian Scridon \\ West University of Timisoara, Faculty of Letters, History and Theology, \\ Bdul. Vasile Pârvan 4, Timişoara 300223, Romania \\ Email address: alin.scridon@e-uvt.ro
}

(9) $\odot \Theta \Theta$

\begin{abstract}
The church press published important documents regarding the religious life of Romanians from Transylvania and Banat. This publication also included details regarding the religious life of the school from Banat. The Biserica și Şcoala magazinewas published in the western historical Banat, in Arad. This was possible due to the fact that Timisoara, the most important city in Banat, had a Romanian Orthodox Deanery that was dependent on the Diocese of Arad, before the establishment of the Diocese of Timisoara in 1939.The Caransebes Diocese' magazine Foaia Diecezană (The Diocesan Sheet) provided the clergy and the faithful with information on Christian spirituality. Along the aforementioned magazines, there were a few newspapers which have enriched this field's literature. Based on those covered by the study, we find that the media made an overwhelming contribution to the dissemination of the biblical information during that particular period of time.
\end{abstract}

Keywords: Banat, Timisoara, Bible, New Testament, Biserca si Scoala, Foaia Diecezana.

\section{INTRODUCTION}

The historical Banat is a province that extends between the Danube, Mureş, Tisa and the Carpathian Mountains (Munteanu, 2006, p. 46). In the $18^{\text {th }}$ and $19^{\text {th }}$ centuries, the territory of the historical Banat spanned across $28.526 \mathrm{~km}^{2}$. After the Second World War, the $28.526 \mathrm{~km}^{2}$ were divided as follows (Ciuruşchin, 2010, p. 141): $18.966 \mathrm{~km}^{2}$ - to Romania, $9.276 \mathrm{~km}^{2}$ - to Yugoslavia and a north-western corner, situated at the junction of Mureş with Tisa, became part of Hungary (meaning $284 \mathrm{~km}^{2}$. The Banat region was a bridge of contact between the Central and South-Eastern Europe and it developed, along the centuries, its own particularity with distinct ethical, cultural, and spiritual characteristics.

In terms of the population from the historical Banat, at the beginning of the 20th century, the census in 1919 showed a number of 1.366.218 inhabitants (Munteanu, 2006 , p. 283). Out of 16 nationalities, the Romanians were a majority $-41,7 \%$, followed by the Germans with $22,5 \%$, the Serbians with $17 \%$, and the Hungarians with 
13,3\% (Munteanu, 2006, p. 389).The Romanians and the Serbians were Christians, predominating in percentage, and a significant number of Romanised Germans and Hungarians, with a lower percentage, were recorded in the protestant, Greek-Catholic or mosaic confessions (Scridon, 2010, pp. 98-113).

Starting with the mid- $16^{\text {th }}$ century and up to the beginning of the $18^{\text {th }}$ century the historical Banat was under Turkish rule. This way it was established the Pashalik of Timişoara. During the Austro-Turkish War, between 1716 and 1718, the region of Banat was under Austrian rule, but at the same time recognized as an imperial province by the Peace Treaty of Passarowitz (1718).

The historical Banat was integrated into the Habsburg Empire and it owned a particular position in the area situated at the European periphery (the newly acquired part to the continent)in conjunctionwith the classical Europe. This region was between the Eastern-Balkan and the Western-Central European area, gravitating towards the Southern area, in the continuous oscillation between Northern and Southern part of Europe (Bocşan, 1986, p. 7).

On the $18^{\text {th }}$ of April 1768 the Habsburg Monarchy strengthened the eastern border of Banat by establishing a military border in this area.This included the territories between Orşova and Caransebeş, with the headquarters in Mehadia. In 1775to the military borderwere added new territories such as Tara Almăjului and the area of Clisura Dunării, up to the lower course of Nera river (Bocşan, 1986, p. 102). The military border included $1 / 4$ of the Romanian Banat territory and $1 / 5$ of its population.

In the same century the Habsburg Monarchy, in striving to consolidate the Austrian rule andefficiently explore the natural resources, colonized the inhabitants from the southern Germany and Austria. Referring to this aspect,the famous Romanian historian NicolaeIorgawrote: "in 1718 the imperialists have widened the borders of their possessions in this Orient where they were claiming the entire heritage of the royal Hungary, wanting to turn mere demands into an effective domination. Eugeniu de Savoya gave them the domination over Banat of Timişoara, which he had exemplarily organized, by colonizing it with occidental elements, French and Spanish peopletogether with Serbian immigrants, some from an earlier age, and Romanian people..." (Iorga, 1985, p. 22).

The settlers had significantly contributed to the economic development of the area, but the local population has always been confronted withnumerous difficulties related to the politics of excessive centralisation. This new historical context will lead to promotion and development of national emancipation movement.

Later on, at the end of the $18^{\text {th }}$ century, the Banat region was incorporated into the Habsburg Kingdom of Hungary (1778 -1780). It happened at the insistence of the Hungarian nobility to the Imperial Court, which amounted claims on this territory. The consequence was the reorganization of Banat. Its former territory was divided into three counties: Timiş, Torontal, and Caraş. The three counties were subordinated to the Hungarian Council, and through it, to the Hungarian government of Pest. From the annexation to Hungary, in Banat will apply only the legislation approved by the Hungarian political council, where the three countiessent their representatives. The Banat Military Border wasan administrative and military structure created with the purpose of defending against Ottoman threat 
(Feneşan, 1997, p. 36) - the southern, the south-eastern and the south-western part of Banat, remained further under the administration of the Empire. The Military Border was headed by the General Military Command of Banat,based in Timişoara and subordinated directly to the Aulic Council of Vienna (Feneşan, 1997, p. 36). From a religious aspect, following the appearance of Greek Catholicism in Transylvania, therefore from 1698 to 1864, the Orthodox Romanians in the Banat were directed by Serbian hierarchs. After the re-establishment of the Metropolitan church of Ardeal, in 1864, with two suffragan dioceses in Arad and Caransebeş, Andrei Şaguna convened in Sibiu The Romanian Orthodox National Church Congress of the whole metropolitan church,in the fall of 1868. Duringthis congress has been approved the Organic Statute of the Romanian Orthodox Church in Transylvania, ratified by the authorities in May 1869. This is the historic act after which the Transylvanian Church was led, until 1925 (Păcurariu, 2000, pp. 365-366).

Between 1867 and 1918 it was a difficult period for the Romanian clergy (bishops and priests) due to organizational efforts of the metropolitan church in Sibiu, and the two bishoprics of Arad and Caransebeş, which were barely at their beginning. Moreover, the hierarchical separation and theheritage issue caused tensions between the two ethnic groups that lived peacefully in the historical Banat.However, there were many cases when due to a better "financial" delimitation the representatives of the two Churches had appealed for justice. Certainly, the second half of the 19th century and the first half of the 20th century are distinguished through a sustained effort in building churches. From this point on, all the church services were held in Romanian languageonly. All these aspects, divided in parishes, were very well depicted by the scholars from Timisoara, such as: Nicolae Ilieşiu (Ilieşiu, 1943) and Virgil Popovici (Popovici, 1933). They produced two major papers devoted to the historical past of Timisoara, with rich uniquecontent, through which they proved the amplitude of the spiritual and cultural life in the municipality.

In the aforementioned ethnic and confessional context, the biblical message could be disseminated by the official press of the two Orthodox Christian Churches in Banat fromCaransebeş and Arad. I mentioned the town of Arad, which is structural in Transylvania, whereas half of the historical Banat was under canon bishopric of Arad.The Romanian Orthodox Episcopate of Arad had the Biserica si Scoala magazine and the Romanian Orthodox Episcopate of Caransebes owned Foaia Diecezana magazine.

\section{a) The Diocesan Sheet (Foaia Diecezana)}

Foaia Diecezana has been printed for the first time in January 5/17 1886, being the work of the bishop Ioan Popasu. It was registered among the Romanian gazettes of Banat with the longest existence and it played a leading role in the dissemination of articles, studies, calls and news of interest for Romanian people's cultural progress (Foaia Diecezană, 1900-1918). It was issued once a week (on Sunday) and it had a format on two columns and eight pages.

Numerous articles were devoted to the scientific theological study, therefore biblical, but also kepta significant space for the history and Romanian language and literature issues. 
The analysed biblical studieswere signed by a number of priests and theologians from Banat (Scridon, 2014, pp. 702-712). Among the priests that contributed to this paper are: Aureliu Iana from Brădişorul de Jos (Iana, 1898, pp. 3-5; 1910, pp. 2-3); B. Biro from Herendeşti (Biro, 1898, pp. 1-2; 1901, pp. 1-3); Petru Barbu (Barbu, 1901, pp. 2-4); Didon Chircescu-Nazarie (Didon, 1901, p. 4) etc. Several of the biblical studies included in the magazine from Caransebeş were published during the fasting period, especially before the Resurrection of Jesus Christ Celebration (Easter). Dramatic events that occured in the last week before the crucifixion of Jesus Christ were commemorated by the special church services within the Orthodox worship (vigils), but also through these studies that reminded the reader of the suffering of Jesus.

After the Easter celebration, which is in the center of Orthodox Christian spirituality, the period before the Nativity was marked by the presence of an increasing number of Bible studies.

The studies show a preoccupation of the Clergy from Banat to deepen the information contained in the Holy Scriptures.The dissemination ofthe New Testament information through Foaia Diecezanahad a pastoral impact among the faithful from the area were has been published the aforementioned paper.

\section{b) The Church and The School (Biserica si Scoala)}

By 1865 the Bishopric Church of Arad depended canonically by Metropolitan Churcyof Carlovit and the bishops from Arad, such as Precopie Ivaşcovici, urged the pastored clergy to study the church press from Braşov and Sibiu. Therefore, the Banat clerical press situation changed radically with the reinstatement of Metropolitan Church of Sibiu through the Holly Baron Andrei de Şaguna.

Among other church newspapers published under the blessing of the Bishop of Arad, Biserica si Scoala was the most read magazine by the priests and faithful in the jurisdictional territory studied by us: the historical Banat (Vesa, 2006, pp. 356-364).

The first number, of the aforementioned paper, was issued in January the $30^{\text {th }}$ / February the $11^{\text {th }} 1877$, and it was also called "church, scholastic, literary, and economic sheet". Its main objective was, as the title says, the church and scholarly issues. Vicentiu Mangra was the responsible editor, which in our opinion, inserted across the sheet he was leading, the most elevated studies of the entire New-Testament around the Banat church's press.

At the beginning, the magazine has been printed in the typography from Arad, owned by Ştefan Gyulai. Then, on January 1st, 1879 the publication is printed at the Diocesan Typography of Arad, and from 1883 the magazine's text was edited with the new orthography proposed by the Romanian Academy in Bucharest.

Biserica si Scoala has been also coordinated by Augustin Hamsea (the $1^{\text {st }}$ of January 1879 up to $31^{\text {st }}$ of January 1882; 1884-1899); Roman Ciorogaru (1900-1917) and Teodor Botiş (1917-1921) (Vesa, 2006, pp. 356-364). This publication piece could not fulfill its proposed mission without the support of its contributors. Many of them were true church and cultural landmarks of those ages, such as: Vicențiu Babeş, Silvestriu Morariu, Simion Mehedinți, Teodor Ceontea, Constantin Gurban, Ioan Damşaet and so on. 
In its pages can be found various church and laic studies, as well as items related to ecclesiastical history, systematic and practical theology, bibliographies of church'peronalities, and so on. Our scientific approach attests that the New Testament biblical research, that has been found in the pages of the magazine, was not obstructed.However, we must not forget that the articles published, in general, has been addressed to the priests and teachers. Biserica si Scoala published, in each of its issues, vacancy lists for priests and teachers.It was certainly a magazine that had a theological and cultural enrichment for both the priest and the confessional educator.

In early 1916, Biserica si Scoala had 314 subscribers within the 18 deaneries that were canonically dependent to the Diocese of Arad. In the 18 deaneries, there were 588 parishes and 600 schools (Vesa, 2006, p. 362). Within the historical Banat were functioning deaneries from Becicherecul Mare, Cenad, Cichindia, Haşiaşul, Lipova (Vesa, 2006, pp. 197-198), Timişoara, and Vinga (Vesa, 2006, pp. 200, 562).

\section{CONCLUSION}

Following the analysis of biblical studies for the discussed period (1867-1918), we estimate that the articles published in the magazine of Arad were superior to those of Caransebes. The upper level touched by language and information has been raised due to a group of young people, well prepared, which later were elected at the head of the Church's hierarchy as bishops. We could mention here the theologian-scientist Vasile Mangra, which at that time was the editor in charge at Biserica si Scoala. Besides the studies carried by Vasile Mangra (Mangra, 1878, Nr. 2, pp. 1-2; 1878, Nr. 14, pp. 107-108), have contributed Silevstru Morariu (Andrievici, 1883, pp. 131-132) - Metropolitan bishop of Bucovina and Roman Ciorogariu (Ciorogariu, 1911, pp. 1-2) - future bishop of Oradea, etc.

Therefore, the historical Banat' church magazines had been noticed by the elevated studies inserted in its pages. They were much read not only of priests but also by numerous faithful, who have valued the activity of the Church on the publicist land as well.

\section{ACKNOWLEDGEMENT}

This work was supported by the strategic grant POSDRU/159/1.5/S/140863, Project ID 140863 (2014), co-financed by the European Social Fund within the Sectoral Operational Program Human Resources Development 2007-2013.

\section{REFERENCES}

Andrievici, S. M. (1883). Christosŭ a înviatŭ[Christ is Risen]. Biserica si Scól'a,VII(14), 131-132.

Barbu, P. (1901). Isus Cristos - cu cuvintele s. Scripturi, textul de la Neamțu [Jesus Christ -with the words of the Holy Scripture, the Neamt writing].Foaia Diecezană, XVI(38), 2-4.

Bocşan, N. (1986). Contribuții la istoria iluminismului românesc [Contributions to the history of Romanian Enlightenment].Timişoara: Facla Editions. 
Biro, B. H. (1898). În sĕptĕmâna mare [In the Holy Week ]. Foaia Diecezană, XIII(13),1-2.

IDEM (1901). Viața de veci prin Isus Cristos [The eternal life through Jesus Christ]. Foaia Diecezană, XVI(36), 1-3.

Ciorogariu, R. (1911). In săptămâna patimilor [In the Passion Week].Biserica şi Şcoala, . XXXV(14), 1-2.

Ciuruşchin, M. (2010). Proiecte de impărțire a Banatului istoric. Chestiunea Banatului istoric în rapoartele dintre România şi Serbia în cursul primului război mondial [Projects regarding the division of the historical Banat region. The historical Banat subject in the Romanian and Serbian relations during the First World War].Studii şi cercetări. Banatul trecut istoric şi cultural, Editura Institutului de Cultură al Românilor din Voivodina [Studies and researches. The historical and cultural past of Banat, The publishing house of The Cultural Institute of the Romaninans from Voevodina]. Zrenianin - NoviSad: ICRV Editions.

Didon, C. N. (1901). Nascerea lui Isus [The birth of Jesus]. Foaia Diecezană,XVI(51), 4.

Feneşan, C. (1997). Administrațieşifiscalitatê̂nBanatul imperial.1716-1778 [Administration and taxation in the Impeial Banat. 1716-1778].Timişoara:Vest Editions.

Iana, A. (1898). Meditațiuni în sântul post [Meditation during the Holy Fasting]. Foaia Diecezană, XIII(10), 3-5.

IDEM (1919). La înălțarea Domnului [At Ascension of Our Lord]. Foaia Diecezană,XXV(21), 2-3.

Ilieşiu, N. (1943). Timişoara. Monografie istorică [Timişoara. Historical monograph]. Timişoara: Timişoara Editions.

Iorga, N. (1985). Istoria literaturii româneşti [The history if Romanian literature]. Bucureşti: Minerva Editions.

Mangra, V. (1878). Serbatórea botezului (bobotéza) séu epifania [The Feast of the Baptism of the Lord]. Biserica si Scól'a, II(2), 1-2.

IDEM (1878).Duminec'a Floriloru [Palm Sunday]. Biserica si Scól'a, II(14), 107-108.

IDEM (1879). Christos a inviatu! [Christ Is Risen]. Biserica si Scól'a, III(14), 105-106.

IDEM (1882). Isusu Christosu si viati'a lui. Dupre Chateaubriand [Jesus Christ and his life, after Chateaubriand].In: Biserica si Scól'a,VI(52), 515-517.

Munteanu, I. (2006). Banatul Istoric. 1867-1918. Aşezările. Populația [The Historical Banat.1867-1918.Settlements.Population] vol 1.Timişoara: Excelsior Art Editions.

Păcurariu, M. (2000).Istoria Bisericii Ortodoxe Române [The History of the Romanian Orthodox Church]. Bucureşti: Sofia Editions.

Popovici, V. (1933).Ortodoxismul şi Biserica Națională Românească din Timişoara [The Orthodoxism and the Romanian National Church in Timisoara]. Timişoara: Timişoara Editions.

Scridon, A. C. (2010). Structuri confesionale în Timişoara între anii 1867-1918 [Confessional structures in Timisoara between 1867-1918]. Studiişicercetări, Actele Simpozionului „Banatul - trecutistoricşi cultural"[Studies and researches, The Symposium Acts „The historical and cultural past of Banat”]. Zrenianin - Novi Sad: ICRV Editions.

IDEM (2014).Cercetarea ştiințifică noutestamentară promovată de Institutul Teologic din Caransebeş la sfârşitul secolului al XIX-lea şi începutul secolului al XX-lea. O perspectivă ziaristică [The New Testament scientific research, promoted by the Caransebes Theological Instituteat end of the 19th century and beginning of the 20th century. A Jurnalistic Approach] Simpozionul internațional „Taină şi mărturisire" [The International Symposium "Sacrament and Confession”]. Caransebeş: Cluj University Press - Diocese of Caransebeş Editions.

Vesa, P. (2006). Episcopia Aradului. Istorie. Cultură. Mentalități (1706-1918) [The Arad Diocese. History. Culture. Mentalities (1706-1918)]. Cluj-Napoca: Cluj University Press. 